\title{
STUDIES ON WOUND HEALING
}

\author{
BY \\ H. FENTON AND G. B. WEST \\ From the Department of Pharmacology, School of Pharmacy, University of London, \\ Brunswick Square, London, W.C.1
}

(Received February 13, 1963)

\begin{abstract}
Factors affecting the rate of healing of experimental skin wounds in rats have been investigated. The effectiveness of healing was measured by determining the tensile strengths of the incised skin after various time intervals. When the skin histamine content was lowered by treatment with polymyxin B or with compound $48 / 80$, retardation of the healing process was evident from the reduced tensile strengths. When the skin 5-hydroxytryptamine content was lowered by treatment with reserpine, retardation of healing was also found. Heparin increased the rate of healing and more rapid healing was obtained by giving histamine before each dose of heparin. On the other hand, some glucocorticoids markedly inhibited the healing process. Of the constituents of the tissue mast cells, heparin appears to be more important than histamine and 5-hydroxytryptamine in promoting the healing of experimental skin wounds in rats.
\end{abstract}

In experimental wounds in rat skin, tissue mast cells initially disintegrate and later re-accumulate as healing progresses (Wichman, 1955). It might be expected that active substances in mast cells (for example, histamine, 5-hydroxytryptamine and heparin) contribute to the process of healing. Recent investigations, however, have cast doubt on the hypothesis that histamine plays an important role in this process. For example, both Kahlson, Nilsson, Rosengren \& Zederfeldt (1960) and Hvidberg, Jorgensen, Schmidt \& Schou (1961) found that the tensile strength of linear wounds in rats was increased when the histamine content of the skin was lowered by treatment with compound 48/80. On the other hand, Boyd \& Smith (1959) reported that such treatment resulted in a decreased tensile strength, whilst Fiore-Donati \& Moltke (1960) observed no effect on the rate of wound healing when histamine depletion was carried out after incision. These last authors extended their study to show that 5-hydroxytryptamine, as well as reserpine (a drug which depletes tissues of 5-hydroxytryptamine), significantly decreased the tensile strength of healing wounds.

A re-evaluation of the problem was therefore needed, particularly as the conditions in these experiments differed widely. The effects of adrenalectomy and of administration of glucocorticoids have also been studied.

\section{METHODS}

Wounds. Groups of ten rats of the Wistar albino strain were used in most experiments. A few tests were also carried out on groups of Sprague Dawley and August rats. The animals were fed on a cube diet (No. 41B, Associated London Flour Millers) and always had free access to water. With ether anaesthesia, the skin of the back of each rat was lightly shaved and immediately one midline linear incision, $4 \mathrm{~cm}$ long, was made through the whole skin 
thickness with a sharp scalpel. The underlying muscle was not cut. The skin edges were then brought together with three interrupted sutures of sterile black silk thread inserted with a sterile curved needle. No dressing was applied to the wound and the animal was returned to its cage. Groups of rats were killed at intervals up to the 13th post-operative day.

Index of the rate of repair. The tensile strength of the healing wound, recognized as reflecting the rate of repair, was determined by a modification of the method of Boyd \& Smith (1959). After death of the animal, a strip of skin, about $2 \mathrm{~cm}$ wide, was excised with the wound at its centre. The strip was laid on a horizontal wooden board and the skin on one side of the wound was pinned firmly to it. A hook was passed through the skin on the other side of the wound and tied to a string which passed horizontally to a pulley and thence vertically downwards to a metal pan. Weights were added gradually until the wound split, and the value of the weights plus the weight of the pan was taken as the tensile strength of the wound. The values quoted in the Figs. and Tables are either the means for each treated group per $\mathrm{cm}$ length of wound or the means of measurements expressed as percentages of those for control rats of similar sex and body-weight. By this method, differences of $20 \%$ are significant $(P<0.05)$.

Histamine and 5-hydroxytryptamine contents of the wound. After the determination of tensile strength, the strip of skin was divided into two parts by a cut at right angles to the original wound. One part was extracted and assayed for its histamine content, the other for its 5-hydroxytryptamine (Parratt \& West, 1957). All values of these amines are expressed in terms of the bases, and are the means for each group of rats. Differences of $15 \%$ are significant $(P<0.05)$.

Drug treatment. Four types of treatment have been used. In the first (termed "prior treatment") the drugs were injected intraperitoneally for 3 days before wounding. Polymyxin B, a histamine (Bushby \& Green, 1955) but not a 5-hydroxytryptamine liberator (Parratt \& West, 1957), was given in two doses of $2.5 \mathrm{mg} / \mathrm{kg}$ on the first day, two doses of $5 \mathrm{mg} / \mathrm{kg}$ on the second, and two doses of $7.5 \mathrm{mg} / \mathrm{kg}$ on the third; compound $48 / 80$, a liberator of both skin histamine and 5-hydroxytryptamine (Parratt \& West, 1957), was given in two doses of $1 \mathrm{mg} / \mathrm{kg}$ on the first day, two doses of $2 \mathrm{mg} / \mathrm{kg}$ on the second and two doses of $3 \mathrm{mg} / \mathrm{kg}$ on the third; reserpine, a liberator of skin 5-hydroxytryptamine but not of skin histamine (Parratt \& West, 1957), was given in three daily doses of $1 \mathrm{mg} / \mathrm{kg}$.

In the second type of treatment (termed "after treatment") the drugs were injected intraperitoneally after wounding, for the first 3 days in the doses as for the "prior treatment" and then daily either with $5 \mathrm{mg} / \mathrm{kg}$ of polymyxin $\mathrm{B}, 3 \mathrm{mg} / \mathrm{kg}$ of compound $48 / 80$, or $0.5 \mathrm{mg} / \mathrm{kg}$ of reserpine respectively.

In the third type of treatment (termed "chronic treatment") the drugs were injected intraperitoneally for 3 days before wounding and daily after wounding using the doses stated previously.

In the fourth type of treatment, doses of histamine $(0.5 \mathrm{mg} / \mathrm{kg})$, heparin $(1,000 \mathrm{U} / \mathrm{kg})$, histidine $(100 \mathrm{mg} / \mathrm{kg})$, 5-hydroxytryptamine $(25 \mathrm{mg} / \mathrm{kg})$, mepyramine maleate $(25 \mathrm{mg} / \mathrm{kg})$, lysergic acid diethylamide $(1 \mathrm{mg} / \mathrm{kg})$, cortisone acetate $(5$ and $10 \mathrm{mg} / \mathrm{kg})$ or dexamethasone ( 1 and $5 \mathrm{mg} / \mathrm{kg}$ ) were given subcutaneously into the midline of the scruff of the neck anterior to the incision, for 3 days before wounding and daily after wounding.

The skin of Wistar rats at the 14th day of pregnancy was also wounded, the tensile strengths of the wounds being tested 5 days later when the urinary histamine output by the mother was more than 20-times the control value for non-pregnant rats (Telford \& West, 1961). Female August rats bearing a hepatoma (F-Hep) were also used, as these animals excrete large quantities of histamine (Kameswaran \& West, 1962); these rats were wounded on the 7th day after grafting the hepatoma and the tensile strengths of the wounds were measured 5 days later. Other Wistar rats were either subjected to a reduced food intake for 8 days ( $5 \mathrm{~g}$ of diet daily for 3 days before and 5 days after wounding), or partially hepatectomized on the day of wounding (Kameswaran \& West, 1962), or subjected, to cold stress (3 $\mathrm{hr}$ at $4^{\circ} \mathrm{C}$ every day after wounding). 
In later experiments, Wistar rats were adrenalectomized or sham-adrenalectomized, and then maintained on $0.9 \%(\mathrm{w} / \mathrm{v})$ saline; the skin wound for studying tensile strength 5 days later was that used for the operation. Some of these rats received cortisone daily after wounding.

\section{RESULTS}

Effect of sex and weight of rat on the tensile strength of the wound. The tensile strength of wounds in male rats did not differ significantly from that in female rats of the same weight but it was significantly greater in heavier animals than in lighter animals. Fig. 1 shows the values at 5 days after incision plotted against the mean

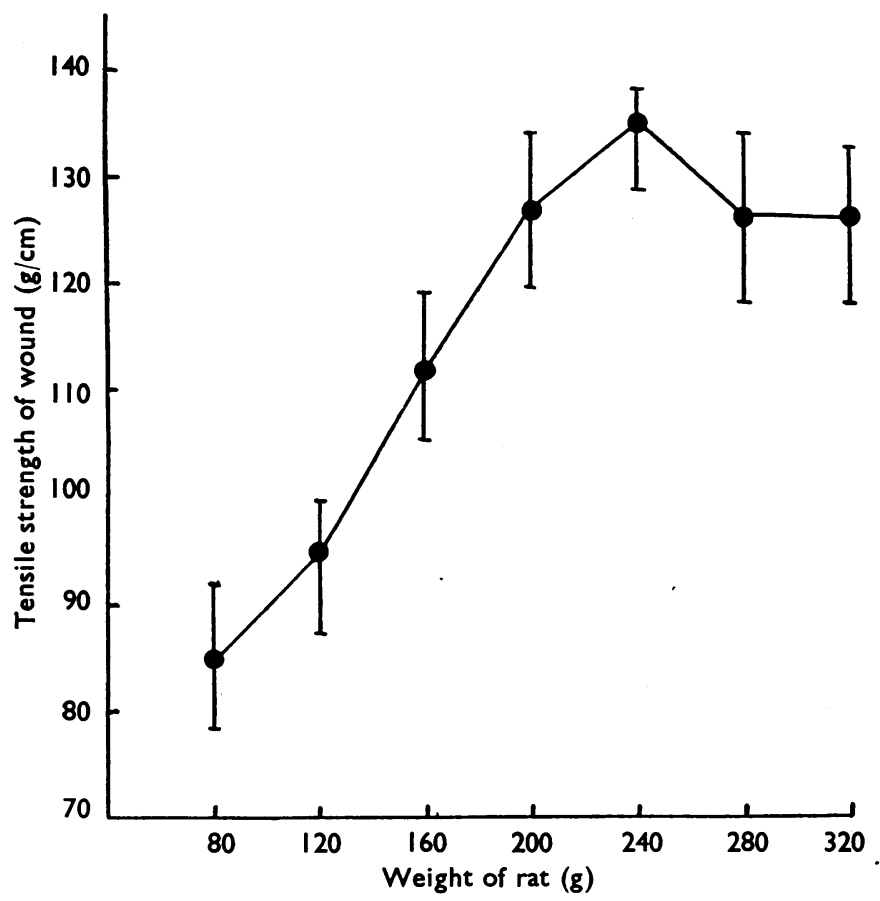

Fig. 1. The relationship between tensile strength of experimental wounds 5 days after incision ( $\mathrm{g} / \mathrm{cm}$ length of wound, ordinate) and the body-weight of rats ( $\mathrm{g}$, abscissa). Each point gives the mean (with the range shown by the vertical line) of the results using four groups each of ten rats.

body-weight. Animals of each sex weighing over $200 \mathrm{~g}$ gave consistent values and were used in the present study for all further comparisons. The tensile strength of wounds in Sprague-Dawley and August rats did not differ appreciably from that in Wistar rats. If the incision was not made immediately after shaving, inconsistent values of tensile strength 5 days after incision were obtained.

Effect of time of measurement of tensile strength of the wound. There was a steady increase in the tensile strength of wounds in rats weighing over $200 \mathrm{~g}$ from. the 3 rd to the 11th day after incision, and almost all wounds in untreated animals 
healed by the 13th day (i.e. the tensile strength exceeded $290 \mathrm{~g} / \mathrm{cm}$ of wound). These results are shown in Fig. 2. In most subsequent experiments, therefore, measurements of tensile strength were made 5 days after incision.

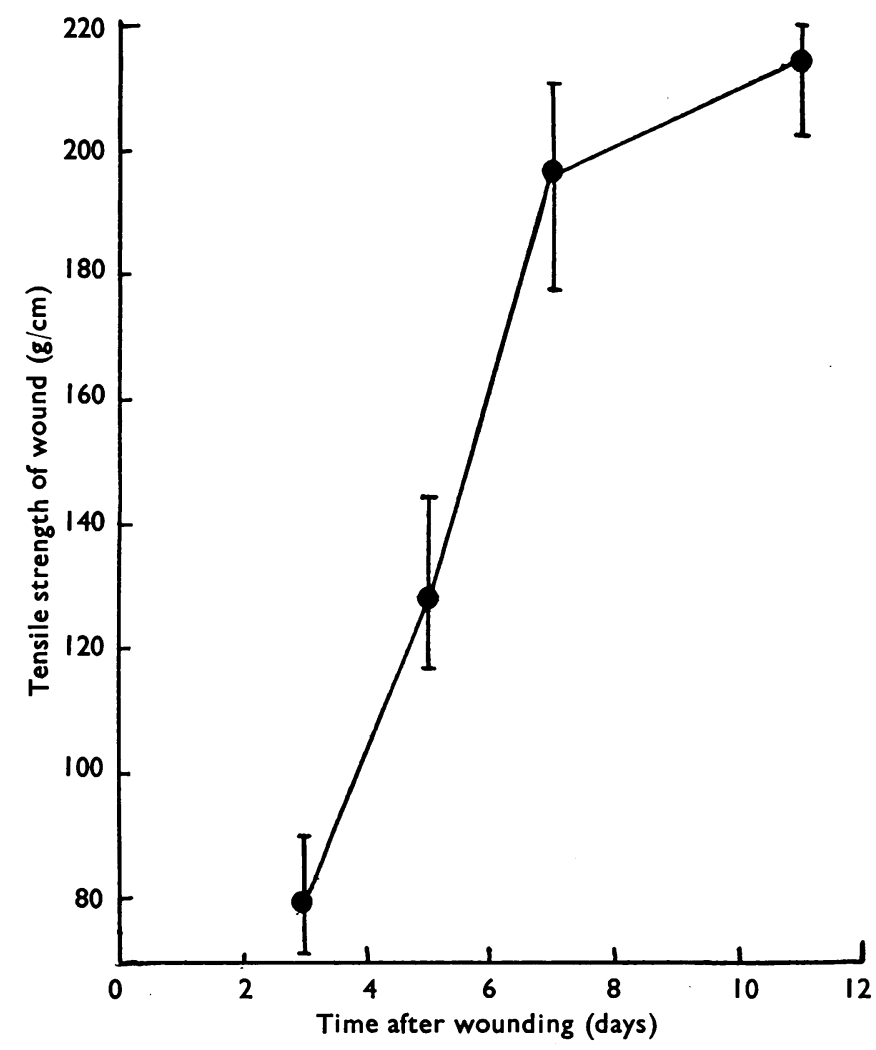

Fig. 2. The tensile strength of experimental wounds $(\mathrm{g} / \mathrm{cm})$ in rats tested at different times after incision. Each point gives the mean (with the range shown by the vertical line) of the results using two groups each of ten rats weighing 200 to $240 \mathrm{~g}$.

Histamine content of the wound. The histamine content of the wounded area decreased to about $40 \%$ on the first day after incision, and at healing time in control rats reached about $80 \%$ of the original value (Fig. 3).

Effect of a preliminary wound on tensile strength of a subsequent wound. When a first wound was made 2 or 3 weeks before a second wound in the same area of skin, the tensile strength of the second wound 5 days after incision was significantly raised (mean \pm s.e. $=130 \pm 3 \%$ of controls). Therefore all later comparisons were made on rats which had not been previously wounded.

Effect of "prior treatment." Depletion of skin histamine by polymyxin B or by compound $48 / 80$ before wounding altered the tensile strength of the wound only trivially when tested 5 days after incision (Table 1). At this time, the histamine content of the wounded area was about $20 \%$ of that of non-treated rats. However, 


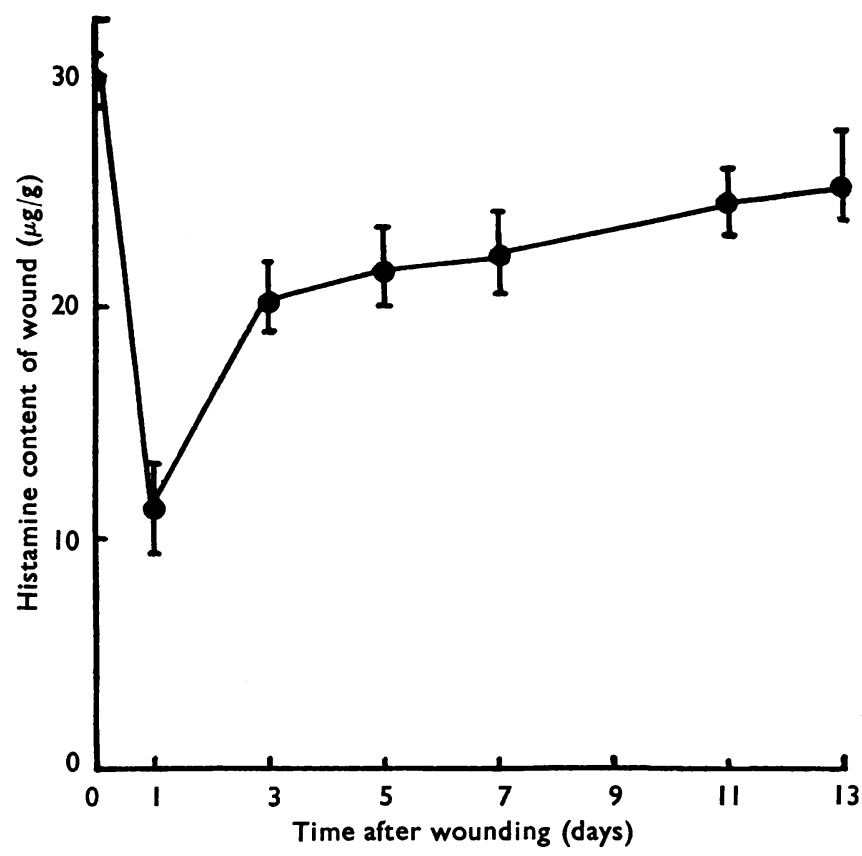

Fig. 3. Histamine content $(\mu \mathrm{g} / \mathrm{g})$ of the excised area containing the experimental wound, tested at different times after incision. Each point gives the mean (with the range shown by the vertical line) of the results using two groups each of ten rats weighing 200 to $240 \mathrm{~g}$.

TABLE 1

EFFECT OF DIFFERENT TREATMENTS WITH DIFFERENT COMPOUNDS ON THE TENSILE STRENGTHS AND HISTAMINE CONTENTS OF EXPERIMENTAL WOUNDS IN RATS

T.S. $=$ tensile strength in $\mathrm{g} / \mathrm{cm}$ of wound. $\mathrm{H}=$ histamine content in $\mu \mathrm{g} / \mathrm{g}$. Measurements were made 5 days after incision

Treatment

\begin{tabular}{|c|c|c|c|c|c|}
\hline \multicolumn{2}{|c|}{ Before incision } & \multicolumn{2}{|c|}{ After incision } & \multicolumn{2}{|c|}{$\begin{array}{l}\text { Before and after } \\
\text { incision }\end{array}$} \\
\hline T.S. & H. & T.S. & H. & T.S. & H. \\
\hline $\begin{array}{r}128 \\
123 \\
102 \\
64\end{array}$ & $\begin{array}{r}22 \\
4 \\
4 \\
15\end{array}$ & $\begin{array}{r}128 \\
124 \\
99 \\
64\end{array}$ & $\begin{array}{r}22 \\
3 \\
3 \\
17\end{array}$ & $\begin{array}{r}128 \\
87 \\
87 \\
65\end{array}$ & $\begin{array}{r}22 \\
1 \\
1 \\
10\end{array}$ \\
\hline
\end{tabular}

healing was delayed in rats receiving compound $48 / 80$ when measured 7 and 11 days after wounding as the tensile strength then was less than $70 \%$ of the control value. Treatment with reserpine similarly delayed healing although the histamine content of the wounded area was about $70 \%$ of that of non-treated rats. Thus there was no relationship between the histamine content of the skin and the rate of wound healing in these experiments. The 5-hydroxytryptamine content of the skin was much reduced by treatment with reserpine (to $11 \%$ of controls) and partially reduced (to $51 \%$ of controls) by treatment with compound 48/80 (Parratt \& West, 1957). 
Effect of "after treatment." Depletion of skin histamine after wounding also did not retard healing at 5 days (Table 1), but the tensile strengths of most of the wounds were significantly reduced at 7 and 11 days. Again the 5-hydroxytryptamine content of the skin was much reduced (to $14 \%$ of controls) by treatment with reserpine although the histamine levels were about $80 \%$ of those in control animals. This result supports the suggestion that the rate of wound healing is independent of the histamine content of the skin.

Effect of "chronic treatment." After this treatment, the tensile strengths of all wounds were much reduced (Table 1). The histamine content of the skin after reserpine was lowered at 5 days but recovered by 11 days despite continued treatment. There was also a partial recovery in the skin histamine level during prolonged treatment with compound $48 / 80$ or with polymyxin B. This has already been reported for compound $48 / 80$ by Riley \& West (1955).

Effect of raised levels of tissue histamine. Daily doses of histamine or histidine reduced the tensile strengths of wounds measured 5 days after incision by about $40 \%$. However, the tensile strengths of the wounds both of rats bearing hepatomata and of rats in the later stages of pregnancy were not significantly different from the values from control rats. Large doses of the antihistamine drug, mepyramine, also did not alter the tensile strength of wounds 5 days after incision.

Effect of raised levels of tissue 5-hydroxytryptamine. Daily doses of 5-hydroxytryptamine reduced the tensile strengths of wounds measured 5 days after incision by about $30 \%$. However, the tensile strengths of the wounds of rats receiving daily doses of the anti-5-hydroxytryptamine drug, lysergic acid diethylamide, were markedly raised, the increase being over $50 \%$ in each of three experiments.

Effect of raised levels of tissue heparin. Daily doses of heparin markedly raised the tensile strengths of wounds measured 5 days after incision. The increase was over $50 \%$ in each of four experiments and the wounds healed quicker than in control rats. Even better healing and a further increase in the tensile strength was achieved when histamine $(0.5 \mathrm{mg} / \mathrm{kg})$ was injected in the mornings, and heparin was given in the afternoons of each day. This drug procedure was used as Riley (1962) suggested that in injury histamine is first released from mast cells and paves the way for the connective tissue cells to receive the heparin which is later released. The tensile strengths after this procedure were the highest recorded in the present work, values being nearly twice those of non-treated rats.

Effect of stress on tensile strength of the wound. Semi-starvation, partial hepatectomy and cold stress, each reduced the tensile strengths of wounds 5 days after incision, by about $35 \%$.

Effect of altered levels of tissue corticosteroids. Adrenalectomy enhanced healing (tensile strengths being increased by about $50 \%$ ), but when cortisone was given to adrenalectomized rats the tensile strengths 5 days after wounding were similar to values for control rats. The operation of sham-adrenalectomy did not significantly alter the healing process, yet injections of cortisone retarded healing in such animals. However, in unoperated animals, both doses of cortisone, as well as the smaller dose of dexamethasone, greatly reduced the tensile strength of wounds at the 5th day (values being about $45 \%$ of those for controls). The larger dose of 
dexamethasone, moreover, completely prevented healing and even at 10 days after wounding signs of adhesion of the cut surfaces were absent.

\section{DISCUSSION}

This work was initiated when it was reported that at least two constituents of tissue mast cells, histamine and 5-hydroxytryptamine, play important roles in the healing of wounds. The results of recent studies in this field by four groups of workers, shown in Table 2, indicated, however, that the evidence was inconclusive. The hypothesis that histamine controls growth, regeneration and repair (Kahlson, 1960) also needed to be tested using experimental wounds. When the methods used by the groups of workers were examined, however, it was clear that the differences found in the tensile strengths of wounds were most probably the result of different techniques. For example, the weight of rat ranged from 100 to $350 \mathrm{~g}$,

TABLE 2

COMPARISON OF SOME OF THE FACTORS IN EXPERIMENTS BY VARIOUS AUTHORS AND THE EFFECTS OF DIFFERENT TREATMENTS ON THE TENSILE STRENGTH OF WOUNDS IN RATS

(a) Treatment before incision, (b) treatment before and after incision, and (c) treatment after incision. Blank spaces show treatments not tested. T.S. $=$ tensile strength. 5-HT=5-hydroxytryptamine

\begin{tabular}{|c|c|c|c|c|c|}
\hline $\begin{array}{l}\text { Factor or } \\
\text { treatment }\end{array}$ & $\begin{array}{l}\text { Boyd \& } \\
\text { Smith } \\
\text { (1959) }\end{array}$ & $\begin{array}{l}\text { Hvidberg } \\
\text { et al: } \\
\text { (1961) }\end{array}$ & $\begin{array}{c}\text { Kahlson } \\
\text { et al. } \\
(1960)\end{array}$ & $\begin{array}{c}\text { Fiore- } \\
\text { Donati } \\
\text { \& Moltke } \\
(1960)\end{array}$ & $\begin{array}{c}\text { Present } \\
\text { work } \\
\text { (1963) }\end{array}$ \\
\hline Sex & - & Female & - & Male & Both \\
\hline Body-weight (g) & $200-300$ & 100 & $200-250$ & $250-350$ & $>200$ \\
\hline Length of wound $(\mathrm{cm})$ & 2 & 6 & 6 & 5 & 4 \\
\hline Days after wounding & 5 & 5 & 5 & 8 & 5 \\
\hline $\begin{array}{l}\text { Measurement with } \\
\text { tensiometer }(\mathrm{T}) \text { or } \\
\text { hook }(\mathrm{H}) \text { and weights }\end{array}$ & $\mathbf{H}$ & $\mathbf{H}$ & $\mathrm{T}$ & $\mathrm{T}$ & $\mathbf{H}$ \\
\hline T.S. $(\mathrm{g} / \mathrm{cm}$ of wound $)$ & 47 & 60 & 200 & 590 & 127 \\
\hline $\begin{array}{l}\text { Histamine depletion } \\
\text { (polymyxin B) }\end{array}$ & - & - & $\begin{array}{c}\text { T.S. } \\
\text { increased } \\
\text { (a) }\end{array}$ & $\begin{array}{l}\text { No effect } \\
\text { (c) }\end{array}$ & $\begin{array}{l}\text { No effect } \\
\text { (a), (c) }\end{array}$ \\
\hline $\begin{array}{l}\text { 5-HT depletion } \\
\text { (reserpine) }\end{array}$ & - & 一 & (a) & $\begin{array}{c}\text { T.S. } \\
\text { decreased }\end{array}$ & $\begin{array}{l}\text { T.S. } \\
\text { decreased }\end{array}$ \\
\hline $\begin{array}{l}\text { Depletion of histamine } \\
\text { and 5-HT } \\
\text { (compound 48/80) }\end{array}$ & $\begin{array}{c}\text { T.S. } \\
\text { decreased } \\
\text { (a), (b) }\end{array}$ & $\begin{array}{l}\text { T.S. } \\
\text { increased } \\
\text { (b) }\end{array}$ & $\begin{array}{l}\text { T.S. } \\
\text { increased } \\
\text { (a) }\end{array}$ & - & $\begin{array}{l}\text { (a), (b), (c) } \\
\text { T.S. } \\
\text { decreased } \\
\text { (a),(b),(c) }\end{array}$ \\
\hline Histamine & $\begin{array}{l}\text { No effect } \\
\text { (a), (b) }\end{array}$ & - & $\begin{array}{l}\text { No effect } \\
\text { (c) }\end{array}$ & - & $\begin{array}{l}\text { T.S. } \\
\text { decreased } \\
\text { (c) }\end{array}$ \\
\hline $5-\mathrm{HT}$ & - & - & - & $\begin{array}{l}\text { T.S. } \\
\text { decreased } \\
\text { (c) }\end{array}$ & $\begin{array}{l}\text { T.S. } \\
\text { decreased } \\
\text { (c) }\end{array}$ \\
\hline
\end{tabular}

the length of experimental wound from 2 to $6 \mathrm{~cm}$, and the measurements of tensile strength with a hook in vitro or a tensiometer in vivo were made at different days after wounding.

An attempt was therefore made to standardize the conditions of wounding and the determination of the rate of healing. In making comparisons, it was found. for example, that the weight but not the sex of rat is important. Further, the measurement of tensile strength of the experimental wound is optimal between the 
5th and 7th day after incision, and a previous wound markedly alters the tensile strength of the second wound. Therefore, for purposes of comparison in the present study, Wistar rats of either sex but weighing 200 to $240 \mathrm{~g}$ were used. These had not been previously wounded. The experimental wounds were $4 \mathrm{~cm}$ long and the rats were killed usually on the 5th day after incision for measurement of the tensile strength using the hook and weight method. Under these conditions, consistent values of the tensile strength were obtained, the mean of 100 observations being $128 \mathrm{~g} / \mathrm{cm}$ length of wound, with a range of 118 to $134 \mathrm{~g} / \mathrm{cm}$.

In the first series of experiments, almost all the tensile strengths of the wounds were much reduced when the skin histamine had been depleted by treatment with polymyxin $B$ or with compound $48 / 80$. However, in one experiment using prior treatment with polymyxin B, thereby reducing the skin histamine to about $20 \%$ of the control value, a retardation of wound healing did not result. This shows that histamine depletion does not always reduce tensile strength and retard healing. It was later found that rats with blood histamine levels raised by administration of histamine or histidine also had retarded rates of healing. A similar result was obtained when rats in the later stages of pregnancy or when carrying a subcutaneous implant of a hepatoma (both conditions producing raised blood histamine levels) were used. Finally, the antihistamine drug, mepyramine, was ineffective in the dose used.

In the second series of experiments, the tensile strengths of the wounds were much reduced when the skin 5-hydroxytryptamine had been depleted by treatment with reserpine or with compound $48 / 80$. However, excess of 5-hydroxytryptamine also delayed healing. 5-Hydroxytryptamine is a potent stimulant of corticotrophin secretion (Moussatche \& Pereiro, 1957), and this in turn releases glucocorticoids which delay healing. The operation of this mechanism is supported by the finding that 5-hydroxytryptamine was ineffective in adrenalectomized animals where the rate of healing was already increased. Reserpine, on the other hand, also stimulates corticotrophin secretion (Kitay, Holub \& Jailer, 1959) but reserpine was effective in adrenalectomized rats (lowering the tensile strength by some $40 \%$ ). Reserpine, in the dosage used $(1 \mathrm{mg} / \mathrm{kg})$, may therefore delay wound healing other than through depletion of 5-hydroxytryptamine. The stress of semi-starvation, another feature of reserpine action, also delayed healing. An unusual result, however, was obtained with lysergic acid diethylamide, an anti-5-hydroxytryptamine drug, which in small dosage markedly increased the tensile strength of the wounds.

In the third series of experiments, a large dose of heparin increased the rate of healing and even better results were obtained by giving histamine before each dose of heparin. Heparin stimulates the formation of collagen (Gross, Highberger \& Schmitt, 1952) and of mitotic figures (Zimmerman \& Celozzi, 1961), and recently it has been shown to antagonize some of the effects of glucocorticoids (Csaba, Toro, Horvath, Acs \& Mold, 1962). Heparin contained in the tissue mast cell may therefore exert all these actions when tissue damage occurs. It may thus be the most important constituent of the tissue mast cell for aiding wound healing.

Lastly, the more potent glucocorticoids markedly inhibited healing. Liberation of these steroids from the adrenal cortex, as after partial hepatectomy, or during 
semi-starvation or cold stress, also greatly delayed healing. On the other hand, adrenalectomy stimulated healing, the stimulation being obviated by glucocorticoid treatment. These results point to the importance of the adrenal cortex and its secretion in wound healing. Clinical suppression of glucocorticoid secretion may therefore result in stimulation of healing, which may be even further stimulated by the effects of heparin given locally. On the evidence of the present experiments, treatment with relatively large doses of reserpine delays wound healing.

\section{REFERENCES}

BOYD, J. F. \& SMITH, A. N. (1959). The effect of histamine and a histamine releasing agent (Compound 48/80) on wound healing. J. Path. Bact., 78, 379-388.

BushBY, S. R. M. \& GREEN, A. F. (1955). The release of histamine by polymyxin B and polymyxin E. Brit. J. Pharmacol., 10, 215-219.

Csaba, G., Toro, I., Horvath, C., Acs, T. \& Mold, K. (1962). Thymus and stress. J. Endocr., 23, 423-431.

FIORE-DONATI, L. \& MolTKe, E. (1960). Effect of reserpine, 5-hydroxytryptamine and polymyxin $B$ on mast cells and tensile strengths of healing wounds. Acta endocr. (Kbh.), 34, 430-436.

Gross, J., Highberger, J. H. \& SCHMTT, F. O. (1952). Some factors involved in the fibrogenesis of collagen in vitro. Proc. Soc. exp. Biol. (N.Y.), 80, 462-465.

Hvidberg, E., Jorgensen, O., SCHMidt, A. \& Schou, J. (1961). Effect of histamine depletion on formation of granulation tissue and healing of linear wounds. Acta pharmacol. (Kbh.), 18, 313-320.

KAHLSON, G. (1960). A place for histamine in normal physiology. Lancet, i, 67-71.

KaHLSON, G., Nilsson, K., Rosengren, E. \& ZederfeldT, B. (1960). Wound healing as dependent on rate of histamine formation. Lancet, ii, 230-234.

Kameswaren, L. \& West, G. B. (1962). Formation of histamine in mammals. J. Physiol. (Lond.), $160,564-571$.

KITAY, J. I., HoluB, D. A. \& JAILER, J. W. (1959). Inhibition of pituitary ACTH release after administration of reserpine or epinephrine. Endocrinology, 65, 548-554.

Moussatche, H. \& Pereiro, N. A. (1957). Release of adrenocorticotrophin by 5-hydroxytryptamine. Acta physiol. lat.-amer., 7, 71-75.

PARRATT, J. R. \& WeST, G. B. (1957). Release of 5-hydroxytryptamine and histamine from tissues of the rat. J. Physiol. (Lond.), 137, 179-192.

RILEY, J. F. (1962). Histamine and heparin in mast cells. Why both ? Lancet, ii, 40-41.

RILEY, J. F. \& WEST, G. B. (1955). Histamine liberation in the rat and mouse. Arch. int. Pharmacodyn., 102, 304-313.

Telford, J. M. \& WeST, G. B. (1961). The effect of age on the formation of histamine in the rat. J. Physiol. (Lond.), 157, 306-314.

Wichman, B. E. (1955). The mast cell count during the process of wound healing; an experimental investigation on rats. Acta path. microbiol. scand., Suppl. 108, 1-35.

Zimmerman, M. \& Celozzi, E. (1961). Stimulation by heparin of parenchymal liver cell proliferation in normal adult rats. Nature (Lond.), 191, 1014-1015. 